\title{
PENGARUH SISTEM PENGENDALIAN INTERNAL TERHADAP DETEKSI KECURANGAN: PADA PT. PEGADAIAN (PERSERO) CABANG PALOPO
}

\author{
A. Nadya Nurul Fadila \\ Jurusan Akuntansi, Universitas Muhammadiyah Palopo \\ anadyanf@gmail.com
}

\begin{abstract}
ABSTRAK
Penelitian ini bertujuan untuk mengetahui dan menganalisis pengaruh sistem pengendalian internal terhadap tingkat deteksi kecurangan pada PT. Pegadaian (Perseo) Cabang Palopo. Variabel independen yang digunakan adalah sistem pengendalian internaldan variabel dependen yang digunakan adalah deteksi kecurangan. Populasi dalam penelitian ini adalah seluruh pegawai pada PT. Pegadaian (Persero) Cabang Palopo. Metode penelitian ini menggunakan pendekatan survey dengan memberikan daftar pernyataan pada PT. Pegadaian (Persero) Cabang Palopo. Kuesioner yang dibagikan kepada responden sebanyak 34 eksamplar. Penelitian ini menggunakan Smart PLS 3 versi 3.2.8. Smart Partial Least Square (PLS) dan tambahan uji validitas dan uji reabilitas. Hasil penelitian ini menunjukkan bahwa sistem pengendalian internal berpengaruh terhadap deteksi kecurangan pada PT. Pegadaian (Persero) Cabang Palopo. yang ditunjukkan dengan nilai signifikan sebesar 0.003 dan nilai $R$ Square untuk variabel deteksi kecurangan adalah 0.623. Perolehan nilai tersebut menjelaskan bahwa pengaruh sistem pengendalian internal terhadap deteksi kecurangan adalah sebesar $62.3 \%$ dan sisanya $37.7 \%$ dipengaruh oleh konstruk lain di luar dari penelitian ini.
\end{abstract}

Kata Kunci: Sistem pengendalian internal, deteksi kecurangan

\section{ABSTRACT}

This study aims to determine and analyze the effect of the internal control system on the level of fraud detection at PT. Pegadaian (Perseo) Palopo Branch. The independent variable used is the internal control system, and the dependent variable used is fraud detection. The population in this study were all employees at PT. Pegadaian (Persero) Branch of Palopo. This research method uses a survey approach by providing a list of statements at PT. Pegadaian (Persero) Branch of Palopo. Questionnaires were distributed to respondents of 34 copies. This research uses Smart PLS 3 version 3.2.8. Smart Partial Least Square (PLS) and additional validity and reliability tests. The results of this study indicate that the internal control system influences the detection of fraud in PT. Pegadaian (Persero) Branch of Palopo. It is indicated by a significant value of 0.003, and the value of $R$ Square for the fraud detection variable is 0.623 . The acquisition value explained that the influence of the internal control system on fraud detection was $62.3 \%$, and other constructs influenced the remaining $37.7 \%$ outside of this study.

Keywords: Internal control system, fraud detection

\section{PENDAHULUAN}

Latar belankang dalam penelitian ini didasarkan pada tiga poin utama yaitu pertama apa sih pentingnya dari penelitian ini?, kedua fenomena/masalah apa yang terjadi sehingga penelitian ini penting untuk diteliti dan ketiga masih terdapat perbedaan pendapat dari penelitian sebelumnya.

Pertama, pentingnya penelitian terletak dari tujuan sistem pengendalian intern itu sendiri. sistem pengendalian intern adalah suatu sistem yang meliputi struktur organisasi dan segala cara serta tindakan yang terkoordinasi dengan tujuan untuk mengamankan harta milik perusahaan dari penyimpangan maupun penyelewengan yang dilakukan oleh pihak didalam 
maupun diluar perusahaan. Dengan adanya sistem pengendalian intern ini tidak dimaksudkan bahwa penyimpangan dan penyelewengan sama sekali tidak akan terjadi. Akan tetapi diharapkan dapat menekan terjadinya penyimpangan dan penyelewengan dalam batas-batas yang layak sehingga dapat dilakukan tindakan perbaikan yang tepat oleh pihak manajemen perusahaan (Rustini, 2014).

Kedua, adapun fenomena yang menjadi pokok masalah dalam penelitian ini sehingga penelitian ini penting untuk diteliti, yaitu Fenomena kasus kecurangan yang terjadi di PT. Pegadaian Cabang Pungkur Kota Bandung dimana dalam kasus tersebut pimpinan bersama analisis kredit yang melakukan kecurangan kredit dengan tidak menerapkan prinsip kehati- hatian dan tidak sesuai dengan prosedur penyaluran kredit. PT. Pegadaian pada periode 2008-2010 telah menggelontorkan dana krista (dana untuk modal) sebesar Rp. 63 miliar untuk disalurkan kepada 21.300 nasabah. Tapi, dalam penyalurannya ditemukan sejumlah dana yang tidak bias dipertanggungjawabkan dan terdapat sejumlah nasabah fiktif. Dari aksi pimpinan dan analisis kredit tersebut Negara ditaksir merugi Rp.21 miliar (Tempo.com).

Saat ini kecurangan adalah sesuatu hal yang sering dilakukan seseorang dalam suatu organisasi. Kecurangan atau fraud di Indonesia marak terjadi akhir-akhir ini, di mana hal tersebut menjadi pusat perhatian berbagai media di Indonesia maupun di dunia. Kecurangan yang dilakukan seseorang, seberapa besar pun kecurangan tersebut akan berdampak cukup fatal bagi perusahaan. Kecurangan dalam laporan keuangan dibandingkan dengan bentuk kecurangan lainnya yang dilakukan karyawan perusahaan, biasanya memiliki dampak kerugian aset yang lebih tinggi pada perusahaan yang menjadi korban. Kecurangan pada umumnya disebabkan oleh dorongan untuk memanfaatkan kesempatan atau dapat pula disebabkan tekanan untuk melakukan penyelewengan secara terstruktur. Para pelaku kecurangan selalu berusaha memanfaatkan setiap kesempatan yang ada untuk memperoleh keuntungan bagi dirinya. Akibatnya tindakan tersebut menimbulkan kerugian bagi pihak peusahaan.

Kecurangan diartikan sebagai sikap seseorang yang tidak mau berusaha untuk mendapatkan apa yang diinginkan dengan cara bekerja keras melainkan untuk mendapatkan apa yang diinginkan itu, maka seseorang akan menggunakan jalur jalan pintas. Seseorang yang melakukan kecurangan akan memiliki sikap serakah, iri, dengki dan biasanya mereka akan mengumpulkan uangnya sebanyak- banyaknya agar dapat dianggap orang lain sebagai orang paling kaya. Apabila itu sudah dapat terlaksanakan maka akan ada kepuasan batin tersendiri. Kecurangan

A. Nadya Nurul Fadila $21 \mid 45$ 
bisa berupa pencurian, penggelapan, penyembunyian, KKN (Kolusi, Korupsi, Nepotisme) dan masih banyak lainnya. Kecurangan yang dilakukan oleh seseorang dalam perushaan dimaksudkan untuk mendapatkan uang yang lebih agar dapat menghimpun kekayaan, dan bisa dilakukan untuk mengamankan kepentingan pribadi (Meliany \& Hernawati, 2013).

Ketiga perbedaan pendapat dari peneliti sebelumnya yaitu berdasarkan penelitian sebelumnya yang dilakukuan oleh Mengacu pada penelitian yang pernah dilakukan (Yuliani, 2018), mengenai pengaruh perilaku tidak etis, pengendalian internal dan budaya organisasi terhadap kecenderungan kecurangan akuntansi. Hasil penelitian yang dilakukan yaitu pengendalian internal berpengaruh positif dan signifikan terhadap kecendrungan kecurangan akuntansi. Sedangkan penelitian yang dilakukan (Ardhi, 2017), mengenai pengaruh tekanan, keefektifan sistem pengendalian internal, perilaku tidak etis, dan jabatan dalam pengelola keuangan terhadap fraud. Hasil penelitian yang dilakukan yaitu keefektifan sistem pengendalian internal berepengaruh negatif terhadap fraud.

Berdasarkan judul dan uraian yang telah dikemukakan sbelumnya, terdapat fenomena yaitu temuan kasus kecurangan, serta adanya research gap dari penelitian terdahulu yang menunjukkan hasil yang berbeda-beda. Sehingga perlu diteliti kembal.:

Berdasarkan latar belakang yang telah diuraian di atas, peneliti ingin mengetahui pengaruh sistem pengendalian intern terhadap deteksi kecurangan pada PT. Pegadaian (Persero) Cabang Palopo.

Berdasarkan latar belakang penelitian tersebut, maka yang menjadi rumusan masalah dalam penelitian ini yaitu apakah sistem pengendalian internal berpengaruh terhadap deteksi kecurangan pada PT. Pegadaian (Persero) Cabang Palopo?

Tujuan penelitian yang ingin di capai adalah untuk mengetahui pengaruh sistem pengendalian internal terhadap deteksi kecurangan pada PT. Pegadaian (Persero) Cabang Palopo.

\section{TINJAUAN PUSTAKA}

\section{Teori Segitiga Fraud (Fraud Triangle Theory)}

Teori ini dicetuskan pertamakali oleh Dr. Donald Cressy, salah seorang pendiri ACFE yang dikutip oleh pengarang auditing antara lain Steve Alberecht dalam bukunya Fraud Examination dan Alvin A. Arend CS dalam Auditing and Assurance Service. Dalam teori segitiga, perilaku 
fraud didukung oleh segitiga unsur yaitu adanya tekanan, kesempatan, dan pembenaran. Tiga unsur itu digambarkan dalam segitiga sama sisi karena bobot/derajat ketiga unsur itu sama (Karyono, 2013: 9).

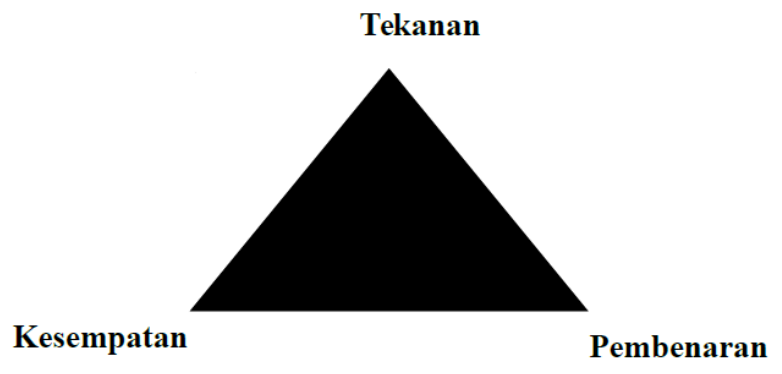

Gambar 2.1

Fraud Triangle

Tekanan: Dorongan seseorang untuk melakukan fraud terjadi pada karyawan (employee fraud) dan oleh manajer (management fraud) dan dorongan itu terjadi anatara lain karena: a) Tekanan keuangan: berupa banyak hutang, gaya hidup melebihi kemampuan keuangan, keserakahan, dan kebutuhan yang tidak terduga, b) Kebiasaan buruk: antara lain kecanduan narkoba, judi, dan peminum minuman keras, c) Tekanan lingkungan kerja: seperti kurang dihargainya prestasi/kinerja, gaji rendah dan tidak puas dengan pekerjaan, d) Tekanan lain: seperti tekanan dari istri/suami untuk memiliki barang- barang mewah.

Kesempatan: kesempatan timbul terutama karena lemahnya pengendalian internal untuk mencegah dan mendeteksi kecurangan. Kesempatan terjadi karena lemahnya sanksi, dan ketidak mampuan untuk menilai kualitas kinerja. Di samping itu tercipta beberapa kondisi lain yang kondusif untuk terjadinya tindak criminal. Menurut Steve Albrecht, ada beberapa factor yang dapat meningkatkan kesempatan untuk melakukan fraud yaitu: a) Kegagalan untuk menertibkan pelaku kecurangan, b) Terbatasnya akses terhadap informasi, c) Ketidaktahuan, malas, dan tidak sesuai kemampuan pegawai, d) Kurangnya jejak audit.

Pembenaran: pelaku kecurangan mencari pembenaran, antara lain, a) Pelaku menganggap bahwa yang dilakukan sudah merupakan biasa/wajar dilakukan oleh orang lain, b) Pelaku merasa berjasa besar terhadap organisasi dan seharusnya ia menerima lebih banyak dari yang telah diterimanya, c) Pelaku menganggap tujuannya baik yaitu untuk mengatasi masalah, nanti akan dikembalikan. 


\section{Teori Berlian Fraud (Fraud Diamond Theory)}

Tulisan di The CPA Journal, bulan Desember 2004, David T. Wolfe dan Dana R. Hermanson memperkenalkan elemen baru dalam fraud triangle, yaitu kemampuan (capability). Dia menganggap bahwa kemampuan merupakan salah satu unsur yang penting ketika seseorang melakukan fraud. Bisa saja seseorang memiliki kesempatan, tekanan dan rasionalisasi, namun jika pelaku tidak memiliki kemampuan maka sulit baginya untuk melakukannya. Model ini diberi nama fraud diamond (Tampubolon, 2005: 37).

Keempat elemen terjadinya fraud menurut diamond theory di gambarkan sebagai berikut:

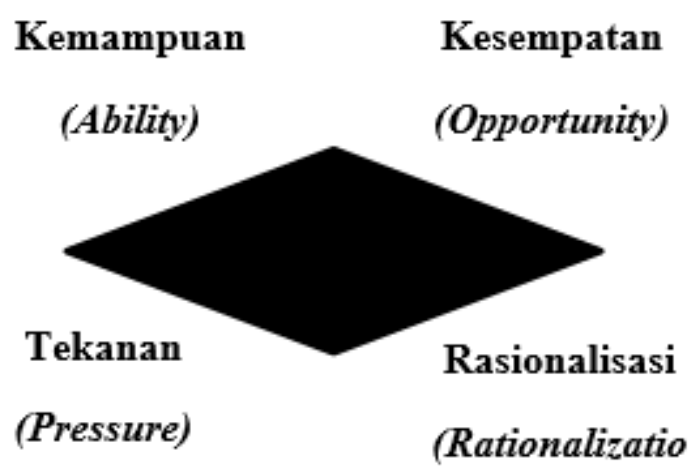

Gambar 2.2

Diamond Theory

Sumber : (Tjahjono, Taringan, Untung, Efendi, \& Hardjanti, 2013: 8)

Diamond theory menggambarkan keempat elemen tersebut saling terkait dan kemampuan (capability) memberikan kontribusi utama sebagai penyebab terjadinya fraud sehingga perlu dinilai atau ditinjau secara eksplisit dan terpisah. Dengan begitu, teori ini memberi sudut pandang yang lebih luas dari sisi opportunity dimana faktor situasi dan lingkungan ikut dipertimbangkan dalam standar pemeriksaan (Priantara, 2014: 48).

\section{Fraud Pentagon}

Fraud Model sudah berkembang dengan pesat dalam beberapa tahun terakhir ini,

pertama kali fraud model ditemukan oleh Donald R.Cressey (1953) yang kemudian dikenal sebagai fraud triangle. fraud triangle menggambarkan faktor-faktor yang menyebabkan terjadinya kecurangan. fraud triangle kemudian berkembang menjadi fraud diamond yang 
ditemukan oleh Wolfe dan Hermanson (2004). Perkembangan model fraud terbaru ditemukan oleh Jonathan Marks (2012) yang disebut sebagai fraud pentagon. Perbedaan nyata antara fraud triangle, diamond fraud dan fraud pentagon adalah dalam fraud triangle dan diamond fraud berfokus pada kecurangan yang dilakukan pada tingkat manajemen tingkat menengah sedangkan fraud pentagon mempunyai skema kecurangan yang lebih luas dan menyangkut manipulasi yang dilakukan oleh CEO atau CFO (Aprilia, 2017). Di bawah ini adalah gambar dari fraud pentagon:

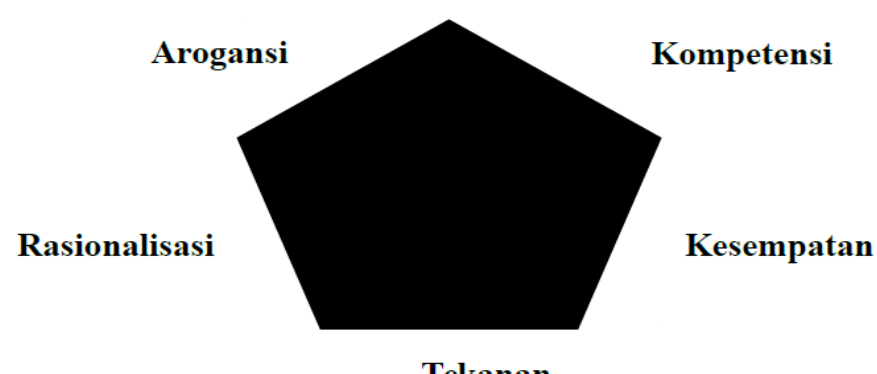

Gambar 2.3

Fraud Pentagon

Sumber: Marks dalam (Aprilia, 2017)

Unsur-unsur yang terkandung dalam fraud pentagon, (Aprilia, 2017) yaitu pertama, arogansi merupakan sifat kurangnya hati nurani yang merupakan sikap superioritas atau adanya sifat congkak pada seseorang yang percaya bahwa pengendalian internal tidak dapat diberlakukan secara pribadi. Kesombongan ini muncul dari keyakinan bahwa dirinya mampu melakukan kecurangan dan kontrol yang ada tidak dapat menimpa dirinya sehingga pelaku kecurangan biasanya berpikir bebas untuk melakukan kecurangan tanpa takut adanya sanksi yang akan menjeratnya.

Kedua, kompetensi adalah dalam hal seseorang untuk melakukan fraud. Dengan demikian dapat disimpulkan bahwa kompetensi merupakan kemampuan karyawan untuk menembus pengendalian internal yang ada di perusahaannya, mengembangkan strategi penggelapan yang canggih, dan mampu mengendalikan situasi sosial yang mampu mendatangkan keuntungan baginya dengan cara mempengaruhi orang lain agar bekerja sama dengannya.

Ketiga, kesempatan yaitu kontrol yang lemah memberikan kesempatan bagi seseorang untuk melakukan penipuan. Terbukanya kesempatan dikarenakan si pelaku percaya bahwa aktivitas A. Nadya Nurul Fadila $25 \mid 45$ 
mereka tidak akan terdeteksi. Andaikan tindakan tersebut diketahui, maka tidak akan ada tindakan serius untuk menanggapi hal tersebut. Peluang biasanya terkait dengan lingkungan dimana perbuatan itu akan terjadinya, hal ini disebabkan karena pengendalian internal yang lemah pengawasan manajemen yang kurang memadai, dan prosedur yang dijalankan tidak jelas.

Keempat, tekanan yaitu dengam adanya motivasi untuk melakukan dan menyembunyikan penipuan yang dilakukan. Seseorang melakukan penggelapan uang perusahaan karena adanya tekanan yang menghimpitnya, tekanan itu dapat berupa adanya kebutuhan mendesak yang harus segera diselesaikan (tekanan keuangan) dan hal ini tidak dapat dibagikan kepada orang lain. Msalah tersebut akan ditutup rapat-rapat oleh orang bersangkutan dan menjadi permasalahan yang non-hareable baginya.

Kelima, rasionalisasi yaitu dengan adanya pemikiran untuk membenarkan kecurangan yang sudah terjadi. Rasionalisasi merupakan pembenaran terhadap tindakan yang akan dilakukan. Para pelaku kecurangan biasanya akan mencari berbagai alasan yang rasional untuk mengidentifikasi tindakan mereka. rasionalisasi diperlukan untuk mencerna perilakunya yang melawan hukum untuk tetap mempertahankan jati dirinya sebagai orang yang dipercaya.

\section{Sistem Pengendalian Internal}

Sistem Pengendalian internal adalah proses yang dijalankan untuk menyediakan jaminan memadai bahwa tujuan-tujuan pengendalian telah dicapai. Pengendalian internal adalah sebuah proses karena ia menyebar keseluruh aktiva pengoprasian perusahaan dan merupakan bagian integral dari aktivitas manajemen (B. Romney \& Steinbart, 2014: 226).

Menurut PP Nomor 60 tahun 2008 menyatakan bahwa sistem pengendalian intern adalah proses yang integral pada tindakan dan kegiatan yang dilakukan secara terus-menerus oleh pimpinan dan seluruh pegawai untuk memberikan keyakinan memadai atas tercapainya tujuan organisasi melalui kegiatan yang efektif dan efisien, keandalan pelaporan keuangan, pengamanan aset Negara, dan ketaatan terhadap peraturan perundang- undangan.

Pengendalian internal adalah proses, kebijakan, dan prosedur yang dirancang oleh manajemen untuk memastikan pelaporan keuangan yang andal dan pembuatan laporan keuangan sesuai dengan kerangka akuntansi yang berlaku. Pengendalian internal membahas hal-hal seperti sikap manajemen terhadap pengendalian, kompetensi pegawai inti/kunci, penilaian risiko, akuntansi, dan sistem informasi keuangan lainnya yang digunakan, serta kegiatan pengendalian tradisional 
(Tuanakotta, 2013: 352). Berdasarkan pengertian-pengertian pengendalian internal tersebut, kita dapat memahami bahwa pengendalian internal merupakan suatu proses yang terdiri dari kebijakan dan prosedur yang dibuat untuk dilaksanakan oleh orang-orang untuk memberikan keyakinan yang memadai dalam pencapaian tujuan-tujuan tertentu yang saling berkaitan. Dengan adanya penerapan pengendalian intern dalam setiap kegiatan operasi perusahaan, maka diharapkan tidak akan terjadi tindakan-tindakan penyelewengan yang dapat merugikan suatu organisasi.

Definisi diatas dapat disimpulkan bahwa sistem pengendalian internal adalah kegiatan yang dilakukan dalam organisasi yang berupa proses, kebijakan dan prosedur yang dirancang agar tercapainya tujuan.

Penerapan sistem pengendalian internal bersifat menyatu dan menjadi bagian integral dari kegiatan perusahaan. Ia bukan bagian terpisah dari kegiatan, ataupun ditambahkan ke dalam kegiatan-kegiatan yang telah disusun. Ini tercermin dalam komponen-komponen yang ada dalam sistem pengendalian internal (T. Lestari, 2014). Komponen pengendalian di rancang dan diimplementasikan oleh manajemen untuk memberikan kepastian yang layak bahwa tujuan pengendalian telah tercapai. Setiap komponen mengandung banyak pengendalian, tetapi auditor hanya berfokus pada pengendalian yang di rancang untuk mencegah dan mendeteksi salah saji material dalam laporan keuangan. Meliputi (Jusuf, 2014:

363) :

Pertama, lingkungan pengendalian, mencakup fungsi tata kelola dan menejemen, serta sikap dan kesadaran, dan tindakan pihak yang bertanggungjawab atas tata kelola dan manajemen atas pengendalian internal entitas dan pentingnya pengendalian tersebut dalam entitas. Lingkungan pengendalian terdiri dari tindakan-tindakan, kebijakan-kebijakan, dan prosedur-prosedur yang mencerminkan prilaku yang menyeluruh manajemen puncak, para direktur, dan pemilik entitas tentang pengendalian internal dan arti pentingnya bagi entitas.

Kedua, proses penilaian resiko entitas, untuk pelaporan keuangan adalah identifikasi dan analisis risiko yang dilakukan manajemen berkaitan dengan pemyusunan laporan keuangan yang sesuai dengan kerangka pelaporan keuangan entitas yang berlaku. Proses penilaian entitas membentuk suatu basis bagi manajemen untuk menentukan bagaimana resiko dikelola. Jika proses tersebut sudah tepat sesuai dengan kondisinya, termasuk sifat ukuran, dan kompleksitas 
entitas, maka hal ini membantu auditor dalam mengidentifikasi risiko kesalahan penyajian material. Ketepatan atas kesesuaian proses penilaian resiko entitas dengan kondisinya di tentukan oleh auditor.

Ketiga, sistem informasi dan komunikasi yaitu suatu sistem informasi terdiri dari infrastruktur (komponen fisik dan perangkat keras), perangkat lunak, orang, prosedur dan data. Proses pelaporan keuangan suatu entitas juga mencangkup penggunaan entri jurnal nonstandar untuk mencatat transaksi atau penyesuaian yang tidak berulang dan tidak biasa. Sebagai contoh penyesuaian untuk konsolidasi dan entri untuk kombinasi bisnis atau penghapusan yang tidak berulang seperti penurunan nilai suatu asset. Komunikasi oleh entitas tentang peran dan tanggungjawab pelaporan keuangan dan hal-hal signifikan yang berkaitan dengan pelaporan keuangan mencangkup penyediaan pemahaman peran dan tanggung jawab individu terkait dengan pengendalian internal atas pelaporan keuangan.

Keempat, aktivitas pengendalian adalah kebijakan dan prosedur, selain yang tercakup dalam keempat komponen pengendalian yang lain, yang membentuk dalam memastikan bahwa tindakan yang diperlukan dilakukan untuk menghadapi risiko guna tercapainya tujuan entitas. Banyak aktivitas pengendalian yang secara potensial bisa dilakukan pada setiap entitas baik bersifat manual maupun terotomatisasi.

Kelima, pemantauan terhadap pengendalian adalah suatu proses untuk menilai efektivitas pelaksanaan pengendalian internal. Kegiatan ini melibatkan penilaian evektivitas pengendalian secara berkala dan tepat waktu, serta melakukan tindakan perbaikan yang diperlukan. Manajemen melakukan pemantuan pengendalian melalui aktivitas yang sedang berlangsung, pengevaluasian secara terpisah atau kombinasi dari keduanya. Aktivitas pengendalian dapat mencangkup penggunaan informasi yang berasal dari komunikasi dengan pihak eksternal atau area yang menjadi perhatian yang memerlukan perbaikan.

Kelima komponen tersebut akan bekerja secara bersama untuk mengeliminasi atau mengurangi kesempatan bagi pegawai dan pihak lain untuk melakukan kecurangan. Suatu lingkungan pengendalian yang baik dapat menciptakan suatu sauna dimana perilaku yang baik dapat diterapkan, Pegawai yang jujur yang diterima, dan seluruh pegawai mengetahui tentang tanggung jawab masing-masing (Suradi, 2014: 194).

(Jusuf, 2014: 356) pada umumnya manajemen memiliki tiga tujuan umum dalam merancang 
suatu sistem pengendalian internal yang efektif yaitu pertama, keandalan pelaporan keuangan entitas. Manajemen bertanggung jawab untuk menyususn laporan keuangan bagi investor, kreditur, dan pihak- pihak lainya. Manajemen memiliki tanggung jawab hukum dan professional untuk memastikan bahwa informasi telah disajikan sesuai dengan persyaratan pelaopran yang di tetapkan Ikatan Akuntan Indonesia (IAI) dan International Financial Report Standard (IFRS). Tujuan pengendalian internal yang efektif atas pelaporan keuangan adalah untuk memenuhi tanggungjawab pelaporan keuangan ini. Kedua, efektivitas dan efisiensi operasi entitas. Pengendalian dalam suatu entitas akan mendorong efektivitas dan efisiensi penggunaan sumber-sumber secara optimal untuk mencapai tujuan entitas. Tujuan utama pengendalian ini adalah untuk memberi informasi keuangan dan non-keuangan yang akurat tentang operasi entitas untuk pengambilan keputusan. Dan ketiga, kesesuaian dengan undangundang dan peraturan- peraturan. Entitas-entitas publik, non-publik, dan organisasi nirlaba berkewajiban untuk menaati banyak undang-undang dan peraturan- peraturan. Sebagian diantaranya hanya menyangkut akuntansi secara tak langsung, namun ada juga yang langsung berkaitan dengan akuntansi, seperti misalnya undang- undang perpajakan.

Berdasarkan tujuan tersebut apabila dilaksanakan dengan baik dan benar, sistem pengendalian internal akan memberi jaminan dimana seluruh bagian dalam perusahaan mulai dari pimpinan hingga pegawai, akan melaksanakan tugasnya dengan jujur dan taat pada peraturan. Sehingga, tidak akan terjadi penyelewengan yang dapat menimbulkan kerugian bagi perusahaan. Manejemen merancang sistem pengendalian internal untuk

mencapai ketiga tujuan di atas. Dimulai dari pengauditan atas laporan keuangan dan audit atas pengendalian internal, kemudian auditor fokus pada reliabilitas laporan keuangan dan pengendalian atas operasi, serta kesesuaian dengan undang-undang dan peraturan-peraturan yang dapat secara material mempengaruhi laporan keuangan.

\section{Deteksi Kecurangan}

Berikut ini dikutip beberapa definisi mengenai fraud, (Karyono, 2013: 2) yaitu menurut W. Steve Albrecht dan Chad D. Albrecht dalam buku mereka, Fraud Examination: fraud adalah suatu pengertian umum dan mencakup beragam cara yang dapat digunakan dengan cara kekerasan oleh seorang untuk mendapatkan keuntungan dari orang lain melalui perbuatan yang tidak benar. Menurut Association of Certified Fraud Examiner (ACFE) dalam Fraud Examiners

A. Nadya Nurul Fadila $29 \mid 45$ 
Manual 2006: fraud (kecurangan) berkenaan dengan adanya keuntungan yang diperoleh seseorang dengan menghadirkan sesuatu yang tidak sesuai dengan keadaan yang sebenarnya. Menurut Blaks Law Dictionary yang merupakan kamus hukum di Amerika Serikat: kecurangan mencakup segala macam yang dapat dipikirkan manusia dan yang diupayakan oleh seseorang untuk mendapatkan keuntungan dari orang lain dengan saran yang salah atau memaksakan kebenaran dan mencakup semua cara yang tidak jujur yang menyebabkan orang lain tertipu. Menurut G. Jack Balogna dan Robert Lindquist dalam Fraud Auditing and Accounting Forensic: fraud (kecurangan) adalah sekumpulan tindakan yang tidak diizinkan dan melanggar hukum yang ditandai dengan adanya unsur kecurangan yang disengaja.

Beberapa definisi diatas dapat disimpulkan bahwa fraud (kecurangan) adalah salah satu bentuk kejahatan yang dilakukan seseorang yang merugikan orang lain dan melanggar hukum.

Association of Certified Fraud Examinations (ACFE) menggunakan istilah fraud tree atau pohon kecurangan dan mengkategorikan kecurangan dalam tiga kelompok (Kuntadi, 2017) yaitu pertama, kecurangan laporan keuangan (financial statement draud). Kecurangan jenis ini dapat dibagi lagi ke dalam beberapa kategori yakni: (1) Timing difference (imporer treatment of sales) yaitu bentuk kecurangan laporan keuangan dengan mencatat waktu transaksi yang berbeda atau lebih awal dengan waktu transaksi yang sebenarnya, misalnya mencatat transaksi penjualan lebih awal dari transaksi sebenarnya; (2) fictious revenues yaitu bentuk laporan keuangan dengan menciptakan pendapatan yang sebenarnya tidak pernah terjadi (fiktif); (3) canceled liabilities and expenses yaitu bentuk kecurangan laporan keuangan dengan menyembunyikan kewajiban-kewajiban perusahaan, sehingga laporan keuangan terlihat bagus; (4) improper disclosure yaitu bentuk kecurangan perusahaan yang tidak melakukan pengungkapan atas laporan keuangan secara cukup dengan maksud untuk menyembunyikan kecurangan-kecurangan yang terjadi diperusahaan, sehingga pembaca laporan keuangan tidak mengetahui keadaan yang sebenarnya terjadi diperusahaan; (5) improper asset valuation yaitu bentuk kecurangan laporan keuangan dengan melakukan penilaian yang tidak wajar atau tidak sesuai prinsip akuntansi yang berlaku umum atas aset perusahaan dengan tujuan untuk meningkatkan pendapatan dan menurunkan biaya. Kedua, Penyalahgunaan aset (asset misappropiatio). Penyalahgunaan aset dapat digolongkan dalam dua jenis kecurangan diantaranya: (1) kecurangan kas (cash fraud) yaitu pencurian kas dan pengeluaran-pengeluaran secara curang seperti pemalsuan cek; (2) kecurangan atas persediaan dan aset lainnya (fraud of

A. Nadya Nurul Fadila $30 \mid 45$ 
inventory and all other asset) yaitu kecurangan berupa pencurian dan pemakaian untuk kepentingan pribadi terhadap persediaan atau aset lainnya. Ketiga, korupsi (corruption). Korupsi terbagi atas: (1) pertentangan kepentingan (conflict of interest) yaitu pertentangan kepentingan yang terjadi ketika karyawan,manajer, dan eksekutif perusahaan memiliki kepentingan pribadi terhadap transaksi yang mengakibatkan dampak kurang baik terhadap perusahaan. Pertentangan

kepentingan termasuk kedalam kategori yaitu, perencanaan, penjualan,rencana pembelian, dan rencana lainnya; (2) suap (bribery) yaitu penawaran, pemberian, penerimaan, atau permohonan sesuatu dengan tujuan untuk memengaruhi pembuat keputusan dalam membuat keputusan bisnis; (3) pemberian illegal (illegal gratuity) yaitu pemberian yang menyerupai suap tetapi pemberian illegal disini bukan untuk memengaruhi keputusan bisnis, melainkan hanya sebuah permainan. Orang yang memiliki pengaruh yang dia berikan dalam negosiasi atau kesepakatan bisnis. Hadiah diberikan setelah kesepakatan selesai;

(4) pemerasan secara ekonomi (economic extortion) pada dasarnya pemerasan secara ekonomi lawan dari suap. Penjual menawarkan untuk memberi suap atau hadiah kepada pembeli yang memesan produk dari perusahaannya.

\section{METODE PENELITIAN}

\section{Tempat dan Waktu Penelitian}

Penelitian ini dilakukan pada PT. Pegadaian (Persero) Cabang Palopoyang beralamat dijalan Andi Kambo dengan rancangan waktu penelitian selama bulanmei sampai dengan juni.

\section{Jenis Penelitian}

Jenis penelitian ini adalah penelitian kuantitatif dengan menggunakan metodesurvey yaitu suatu penelitian yang dilakukan dengan cara terjun langsung kelokasiyang menjadi sampel sehingga peneliti memperoleh data secara langsung dan jelas. Data yang digunakan dalam penelitian ini adalah data primer yang dikumpulkanmelalui pengiriman kuesioner kepadaresponden pada PT. Pegadaian (Persero) Cabang Palopo.

Sumber data dalam penelitian ini diperoleh dari pendapat dan persepsi pegawai PT. Pegadaian (Persero) Cabang Palopo dengan caramenjawab item-item pertanyaan dalamkuesioner yang 
mewakili variabel-variabel yang akan diukur.

\section{Populasi dan Sampel}

Populasi adalah keseluruhan kelompok orang, kejadian, atau hal minat yang ingin peneliti teliti/dikaji Populasi dalam penelitian ini yaitu seluruh pegawai pada PT. Pegadaian (Persero) Cabang Palopo sebanyak 34.

Sampel adalah bagian dari populasi yang ingin diteliti, dipandang sebagai suatu pendugaan terhadap populasi itu sendiri, karena populasi dalam penelitian ini sedikit dan menggunakan seluruh populasi sebagai sampel maka metode sampel yang peneliti gunakan adalah sampel jenuh.

\section{Ikhtisar Pengembalian Kuesioner}

Perhitungan tingkat pengembalian kuesioner responden pada PT. Pegadaian (Persero) Cabang Palopo yang dibagikan dan kembali sebanyak 34.

$$
\begin{aligned}
& \text { N Sampel }=34 \\
& \text { Responden Rate }=34 / 34 \times 100 \%=100 \%
\end{aligned}
$$

Jadi, tingkat pengembalian kuesioner sebesar $100 \%$

Berdasarkan ikhtisar pengembalian kuesioner di atas, memperlihatkan kuesioner yang dibagikan pada PT.Pegadaian (Persero) Cabang Palopo kuesioner yang dibagikan dan kembali sebanyak 34. Apa bila dipersentasekan tingkat pengembalian kuesioner adalah sebesar $100 \%$.

Penyebaran sebanyak 34 kuesioner dilakukan mulai bulan mei sampai juni 2019 sebanyak 34 kuesioner yang kembali seluruhnya dapat diolah. Deskripsi Responden berdasarkan Usia Deskripsi responden berdasarkan usia dapat dilihat pada tabel 3.2 sebagai berikut:

Tabel 3.1

\section{Deskripsi Responden berdasarakan Usia}

\begin{tabular}{|c|l|c|c|}
\hline NO & Usia (Tahun) & $\begin{array}{c}\text { Jumlah } \\
\text { Responden }\end{array}$ & Persentase \\
\hline 1 & $21-30$ & 7 & $20.6 \%$ \\
\hline 2 & $31-40$ & 23 & $67.6 \%$ \\
\hline
\end{tabular}

A. Nadya Nurul Fadila $32 \mid 45$ 


\begin{tabular}{|l|l|c|c|}
\hline 3 & 40 ke Atas & 4 & $11.8 \%$ \\
\hline \multicolumn{2}{|c|}{ Jumlah } & 34 & $100 \%$ \\
\hline
\end{tabular}

Sumber: Data Primer Diolah 2019

Berdasarkan tabel 3.2 di atas, memperlihatkan bahwa persentase terbesar yaitu sebesar $55.56 \%$ responden berusia antara 31-40 tahun, sebanyak $25.40 \%$ berusia 40 tahun ke atas dan sebanyak $19.05 \%$ responden berusia antara 21-30 tahun. Hal ini menunjukkan bahwa hampir sebagian besar responden berada pada usia produktif.

1. Deskripsi Responden berdasarkan Jenis Kelamin

Deskripsi responden berdasarakan jenis kelamin dapat dilihat pada tabel 3.3 sebagai berikut:

Tabel 3.2

Deskripsi Responden berdasarkan Jenis Kelamin

\begin{tabular}{|c|l|c|c|}
\hline NO & $\begin{array}{c}\text { Jenis } \\
\text { Kelamin }\end{array}$ & $\begin{array}{c}\text { Jumlah } \\
\text { Responden }\end{array}$ & Persentase \\
\hline 1 & Laki-Laki & 21 & $61.8 \%$ \\
\hline 2 & Perempuan & 13 & $38.2 \%$ \\
\hline \multicolumn{2}{|c|}{ Jumlah } & 34 & $100 \%$ \\
\hline
\end{tabular}

Sumber: Data Primer Diolah 2019

Berdasarkan tabel 3.2 di atas, memperlihatkan bahwa persentase terbesar yaitu sebesar $55.56 \%$ responden berusia antara 31-40 tahun, sebanyak $25.40 \%$ berusia 40 tahun ke atas dan sebanyak 19.05\% responden berusia antara 21-30 tahun. Hal ini menunjukkan bahwa hampir sebagian besar responden berada pada usia produktif.

2. Deskripsi Responden berdasarkan Jenis Kelamin

Deskripsi responden berdasarakan jenis kelamin dapat dilihat pada tabel 3.3 sebagai berikut:

Tabel 3.3

Deskripsi Responden berdasarkan Tingkat Pendidikan

A. Nadya Nurul Fadila $33 \mid 45$ 


\begin{tabular}{|c|l|c|c|}
\hline NO & $\begin{array}{c}\text { Tingkat } \\
\text { Pendidikan }\end{array}$ & $\begin{array}{c}\text { Jumlah } \\
\text { Responden }\end{array}$ & Persentase \\
\hline 1 & D3 & 2 & $5.88 \%$ \\
\hline 2 & S1 & 32 & $94.12 \%$ \\
\hline \multicolumn{2}{|c|}{ Jumlah } & 34 & 100 \\
\hline
\end{tabular}

Sumber: Data Primer Diolah 2019

Berdasarakan tabel $3.3 \mathrm{di}$ atas, memperlihatkan bahwa persentase yang paling besar yaitu $94.12 \%$ adalah responden yang tingkat pendidikan Strata 1 (S1) dan hanya sebesar $5.88 \%$ adalah responden yang tingkat pendidikan D3. Hasil ini menunjukkan bahwa hampir sebagian besr responden memiliki tingkat pendidikan Strata 1 (S1).

3. Deskripsi Responden berdasarkan Lama Bekerja

Deskripsi responden berdasarkan lama bekerja dapat dilihat pada tabel 3.4 sebagai berikut.

Tabel 3.4

Deskripsi Responden berdasarakan Lama Bekerja

\begin{tabular}{|c|l|c|c|}
\hline NO & $\begin{array}{c}\text { Lama Bekerja } \\
\text { (Tahun) }\end{array}$ & $\begin{array}{c}\text { Jumlah } \\
\text { Responden }\end{array}$ & Persentase \\
\hline 1 & $1-10$ & 19 & $55.9 \%$ \\
\hline 2 & $11-20$ & 11 & $32.4 \%$ \\
\hline 3 & 20 ke Atas & 4 & $11.7 \%$ \\
\hline \multicolumn{2}{|c|}{ Jumlah } & 34 & $100 \%$ \\
\hline
\end{tabular}

Sumber: Data Primer Diolah 2019

Berdasarkan tabel 3.4 di atas, memperlihatkan bahwa persentase lama kerja paling banyak 55.9\% yaitu antara 1-10 tahun, sebanyak 32.4\% responden yang bekerja antara 
11-20 tahun dan persentase yang paling sedikit $11.7 \%$ yaitu responden yang bekerja selama 20 tahun ke atas.

\section{Metode Analisis Data}

Adapun metode analisis yang digunakan untuk mengolah data dalam penelitian ini adalah Smart PLS 3 versi 3.2.8. Menilai Outer Model atau Measurement Model Adapun langkahlangkah yang harus dilakukan dalam PLS, yaitu sebagai berikut:

1. Merancang Model Pengukuran (Outer Model)

Model Pengukuran (Outer model) adalah model pengukuran yang menghubungkan indikator dengan variabel latennya. Model ini digunakan untuk mengetahui validitas dan reliabilitas yang menghubungkan indikator dengan variabel latennya. Indikator dalam penelitian ini adalah refleksi karena variabel laten mempengaruhi indikatornya, dalam menghitung outer model ada tiga cara yaitu sebagai berikut:

a. Validitas Konvengen

Untuk menguji validitas konvergen digunakan nilai outer loading atau loading factor. Suatu indikator dinyatakan memenuhi validitas konvergen dalam kategori baik apabila nilai outer loading $>0.6$.

b. Validitas Diskriminan

Untuk Menguji validitas diskriminan menggunakan nilai cross loading. Suatu indikator dinyatakan memenuhi validitas diskriminan apabila nilai cross loading indikator pada variabelnya adalah yang terbesar dibandingkan pada variabel lainnya.

c. Reliabilitas Komposit

Reliabilitas komposit merupakan bagian yang digunakan untuk menguji nilai reliabilitas indikator-indikator pada suatu variabel. Suatu variabel dapat dinyatakan memenuhi reliabilitas komposit apabila memiliki nilai reliabilitas komposit > 0.7.

2. Merancang Model Struktural (Inner Model) Model struktural (Inner Model)

Merancang Model Struktural (Inner Model) Model struktural (Inner Model) menunjukkan hubungan atau kekuatan estimasi antar variabel laten atau konstruk.

A. Nadya Nurul Fadila $35 \mid 45$ 
a. Koefisien Determinasi $\left(\mathrm{Uji} \mathrm{R}^{2}\right)$

Nilai $R$ Square untuk setiap variabel laten endogen sebagai kekuatan prediksi dari model struktural. Perubahan niali $R$ Square dapat digunakan untuk menjelaskan pengaruh variabel laten eksogen terhadap variabel laten endogen. Nilai $R$ Square di atas 0.7 dikatakan kuat, 0.5 dikatakan sedang dan 0.2 dikatan lemah.

b. Uji Hipotesis

Uji hipotesis pada penelitian ini dilakukan dengan melihat nilai $T$ Statistics dan nilai $P$ Values. Hipotesis penelitian dinyatakan diterima apabila $P$ Values $<0.05$.

\section{DESKRIPSI STATISTIK}

\section{Evaluasi Model Pengukuran (Outer Model)}

a. Validitas Konvergen

Untuk menguji validitas konvergen digunakan nilai outer loading atau loading factor. Suatu indikator dinyatakan memenuhi validitas konvergen dalam kategori baik apabila nilai outer loading > 0.6. Berikut adalah nilai outer loading dari masing-masing indikator pada variabel penelitian:

\section{Tabel 4.1}

\section{Outer Loading}

\begin{tabular}{|l|r|r|}
\hline & Deteksi Kecurangan_(Y) & \multicolumn{2}{|l|}{$\begin{array}{l}\text { Sistem Pengendalian } \\
\text { Internal_(X) }\end{array}$} \\
\hline X1 & & 0,746 \\
\hline X2 & & 0,804 \\
\hline X3 & & 0,734 \\
\hline X4 & 0,976 & 0,730 \\
\hline X5 & 0,943 & 0,733 \\
\hline Y1 & 0,858 & \\
\hline Y2 & & \\
\hline Y3 & & \\
\hline
\end{tabular}

A. Nadya Nurul Fadila $36 \mid 45$ 


\begin{tabular}{|l|r|l|}
\hline Y4 & 0,842 & \\
\hline Y5 & 0,851 & \\
\hline
\end{tabular}

Sumber: Data Primer Diolah 2019

Berdasarkan tabel 4.1 di atas, memperlihatkan bahwa masing-masing indikator variabel penelitian banyak yang memiliki nilai outer loading $>0.7$. Namun, terlihat masih terdapat beberapa indikator yang memiliki nilai outer loading < 0.7 . Nilai outer loading untuk variabel Deteksi Kecurangan dengan lima indikator pengukuran adalah X1 $=0.746, \mathrm{X} 2=0.804$, $\mathrm{X} 3=0.734, \mathrm{X} 4=0.730$, dan $\mathrm{X} 5=0.733$. adapun nilai untuk variabel Sistem Pengendalian Internal dengan lima indikator pengukuran adalah $\mathrm{Y} 1=0.976, \mathrm{Y} 2=0.943, \mathrm{Y} 3=0.858$, Y4 $=0.842$, dan Y5 $=0.851$. Berikut adalah gambar 4.2 hasil nilai loading faktor dari validitas konvergen.

\section{Gambar 4.1 Nilai Loading Factor}

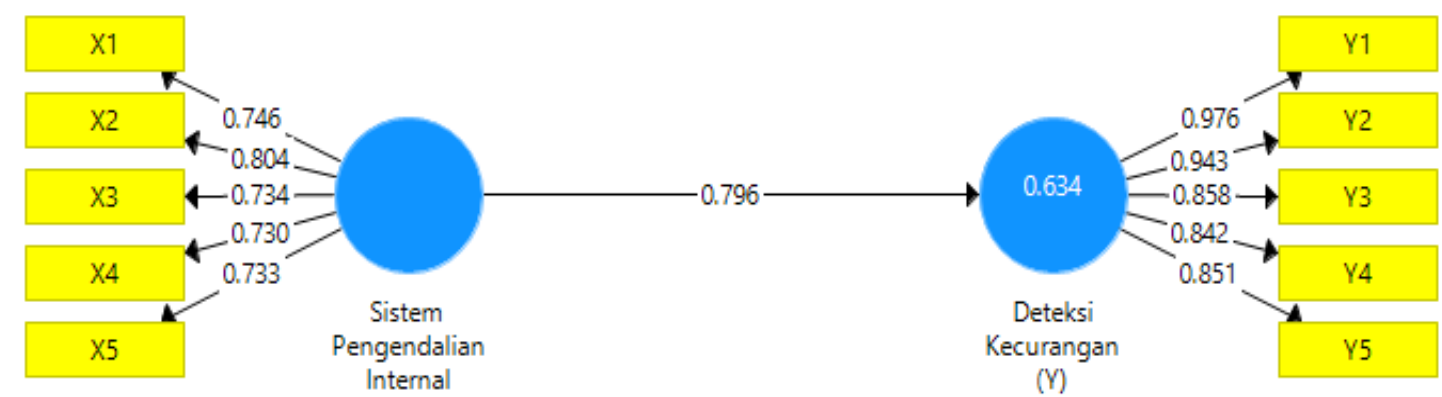

$(X)$

b. Validitas Diskriminan

Untuk Menguji validitas diskriminan menggunakan nilai cross loading. Suatu indikator dinyatakan memenuhi validitas diskriminan apabila nilai cross loading indikator pada variabelnya adalah yang terbesar dibandingkan pada variabel lainnya. Berikut ini adalah nilai cross loading masing-masing indikator:

Tabel 4.2 Cross Loading

\begin{tabular}{|l|l|l|}
\hline & Deteksi Kecurangan_(Y) & Sistem Pengendalian Internal_(X) \\
\hline
\end{tabular}

A. Nadya Nurul Fadila $37 \mid 45$ 


\begin{tabular}{|l|r|r|}
\hline X1 & 0,228 & 0,746 \\
\hline X2 & 0,976 & 0,804 \\
\hline X3 & 0,210 & 0,734 \\
\hline X4 & 0,235 & 0,730 \\
\hline X5 & 0,271 & 0,733 \\
\hline Y1 & 0,976 & 0,804 \\
\hline Y2 & 0,943 & 0,792 \\
\hline Y3 & 0,858 & 0,710 \\
\hline Y4 & 0,842 & 0,577 \\
\hline Y5 & 0,851 & 0,648 \\
\hline
\end{tabular}

Sumber: Data Primer Diolah 2019

Berdasarkan tabel 4.2 di atas, memperlihatkan bahwa masing-masing indikator pada variabel penelitian memiliki nilai cross loading terbesar pada variabel yang dibentuknya dibandingkan dengan nilai cross loading pada variabel lainnya. Berdasarkan hasil yang diperoleh pada variable Deteksi Kecurangan adalah nilai cross loading $\mathrm{Y} 1=0.976>0.804, \mathrm{Y} 2=0.976>$ $0.792, \mathrm{Y} 3=0.858>0.710, \mathrm{Y} 4=0.842>0.577$, dan $\mathrm{Y} 5=0.851>0.648$. Adapun hasil yang diperoleh pada variabel sistem pengendalian internal adalah nilai cross loading $\mathrm{X} 1=0.746>$ $0228, \mathrm{Y} 2=0.804<0.976, \mathrm{Y} 3=0.734>0.210, \mathrm{Y} 4=0.730>0.235$, dan $\mathrm{Y} 5=0.733>2.71$ Dari hasil yang diperoleh dapat dinyatakan bahwa indikator-indikator yang digunakan dalam penelitian ini telah memiliki validitas diskriminan yang baik dalam menyusun variabelnya masing-masing.

\section{c. Reliabilitas Komposit}

Reliabilitas komposit merupakan bagian yang digunakan untuk menguji nilai reliabilitas indikator-indikator pada suatu variabel. Suatu variabel dapat dinyatakan memenuhi reliabilitas komposit apabila memiliki nilai reliabilitas komposit $>0.7$. Berikut ini adalah nilai reliabilitas komposit dari masing-masing variabel yang digunakan dalam penelitian ini: 
Tabel 4.3 Realibilitas Komposit

\begin{tabular}{|c|c|c|c|c|}
\hline & $\begin{array}{c}\text { Cronba ch's } \\
\text { Alpha }\end{array}$ & rho_A & $\begin{array}{c}\text { Reliabilitas } \\
\text { Komposit }\end{array}$ & $\begin{array}{c}\text { Rata- Rata } \\
\text { Varians } \\
\text { Diekstrak } \\
(\text { AVE) }\end{array}$ \\
\hline Deteksi Kecurangan (Y) & 0,937 & 0,950 & 0,953 & 0,802 \\
\hline Sistem Pengendalian Internal (X) & 0,894 & 1,376 & 0,865 & 0,562 \\
\hline
\end{tabular}

Sumber: Data Primer Diolah 2019

Berdasarkan tabel 4.5 di atas, memperlihatkan bahwa nilai reliabilitas komposit semua variabel penelitian > 07. Hasil ini menunjukkan bahwa pada variable deteksi kecurangan dengan nilai reliabilitas komposit adalah 0.953 > dari nilai Cronbach's Alpha 0.937 dan variabel sistem pengendalian $0.865<$ dari nilai Croncbach's alpha 0.894 telah memenuhi reliabilitas komposit sehingga dapat disimpulkan bahwa keseluruhan variabel memiliki tingkat reliabilitas yang tinggi.

\section{Evaluasi Model Struktural (Inner Model)}

a. Koefisien Determinasi $\left(\mathrm{Uji} \mathrm{R}^{2}\right)$

Berdasarkan pengolahan data yang telah dilakukan dengan menggunakan program smartPLS 3 versi 3.2.8 diperoleh nilai koefisien determinasi atau $R$ Square sebagai berikut:

Tabel 4.4 Koefsien Determinasi $\left(\mathrm{R}^{2}\right)$

\begin{tabular}{|l|c|c|}
\hline & R Square & $\begin{array}{c}\text { Adjusted R } \\
\text { Square }\end{array}$ \\
\hline $\begin{array}{l}\text { DETEKSI } \\
\text { KECURANGAN }\end{array}$ & 0.634 & 0.623 \\
$(\mathrm{Y})$ & & \\
\hline
\end{tabular}

Sumber: Data Primer Diolah 2019

Berdasarkan tabel 4.6 di atas, memperlihatkan bahwa nilai $R$ Square untuk variabel deteksi kecurangan adalah 0.623. Perolehan nilai tersebut menjelaskan bahwa pengaruh sistem pengendalian internal adalah sebesar $62.3 \%$ dan sisanya $37.7 \%$ dipengaruh oleh konstruk lain 
di luar dari penelitian ini.

\section{Uji Hipotesis}

Berdasarkan olah data yang telah dilakukan, hasilnya dapat digunakan untuk menjawab hipotesis pada penelitian ini. Uji hipotesis pada penelitian ini dilakukan dengan melihat nilai $T$ Statistics dan nilai $P$ Values. Hipotesis penelitian dinyatakan diterima apabila $P$ Values < 0.05. Berikut adalah adalah hasil uji hipotesis yang diperoleh dalam penelitian ini melalui inner model:

Tabel 4.5

\section{Mean, STDEV, T-Values, P-Values}

\begin{tabular}{|l|l|l|l|c|c|}
\hline & $\begin{array}{c}\text { Sampel } \\
\text { Asli (O) }\end{array}$ & $\begin{array}{c}\text { Rata- Rata } \\
\text { Sampel (M) }\end{array}$ & $\begin{array}{c}\text { Standar Deviasi } \\
\text { (STDEV) }\end{array}$ & $\begin{array}{c}\mathrm{T} \\
\text { Statistik } \\
\text { (|O/ST } \\
\text { DEV|) }\end{array}$ & $\begin{array}{c}\mathrm{P} \\
\text { Values }\end{array}$ \\
\hline $\begin{array}{l}\text { Sistem Pengend } \\
\text { alian Internal_ } \\
(\mathrm{X}) \text {-> Deteksi } \\
\text { Kecuran gan_(Y) }\end{array}$ & 0,796 & 0,725 & 0,269 & 2,957 & 0.003 \\
\hline
\end{tabular}

Sumber: Data Primer Diolah 2019

Berdasarkan tabel 4.7 diatas, memperlihatkan bahwa dari hipotesis yang diajukan dalam penelitian ini, dapat diterima karena pengaruh yang ditunjukkan yaitu variabel Sistem Pengendalian Internal (X) berpengaruh terhadap variabel Deteksi Kecurangan (Y) dengan nilai T Statistik sebesar $2.957>$ T Tabel sebesar 1.693 sedangkan $P$ Values sebesar $0.003<0.05$. Jadi dapat dinyatakan bahwa Sistem Pengendalian Internal dapat mempengaruhi Deteksi Kecurangan, Hipotesis diterima. Berikut adalah gambar 4.5 hasil nilai output bootstrapping dari uji hipotesis.

Gambar 4.2

Output Bootstrapping

A. Nadya Nurul Fadila $40 \mid 45$ 


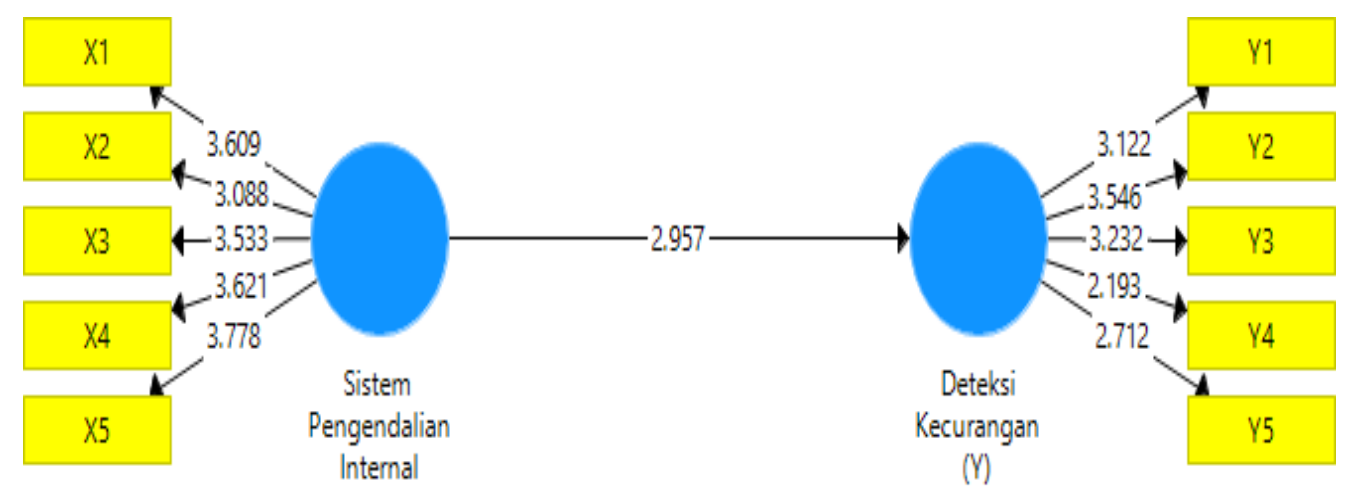

$(X)$

Sumber: Data Primer Diolah 2019

\section{HASIL DAN PEMBAHASAN}

Berdasarkan analisis hasil penelitian menunjukkan bahwa pengendalian internal berpengaruh terhadap deteksi kecurangan. Dari hasil uji hipotesis variabel Sistem Pengendalian Internal (X) berpengaruh terhadap variabel Deteksi Kecurangan (Y) dengan nilai T Statistik sebesar 2.957 $>$ T Tabel sebesar 1.693 sedangkan $P$ Values sebesar $0.003<0.05$. Jadi dapat dinyatakan bahwa Sistem Pengendalian Internal dapat mempengaruhi Deteksi Kecurangan. Dengan demikian hipotesis pertama dinyatakan diterima. Kondisi ini menggambarkan bahwa semakin kuat dan tinggi sistem pengendalian internal yang dimiliki perusahaan maka akan semakin berpengaruh terhadap pendeteksian fraud pada perusahaan tersebut.

Hasil penelitian sejalan dengan teori Fraud Model dimana teori ini sudah berkembang dengan pesat dalam beberapa tahun terakhir ini, pertama kali fraud model ditemukan oleh Donald R.Cressey (1953) yang kemudian dikenal sebagai fraud triangle. fraud triangle menggambarkan faktor-faktor yang menyebabkan terjadinya kecurangan. Fraud triangle kemudian berkembang menjadi fraud diamond yang ditemukan oleh Wolfe dan Hermanson (2004). Perkembangan model fraud terbaru ditemukan oleh Jonathan Marks (2012) yang disebut sebagai fraud pentagon. Perbedaan nyata antara fraud triangle, diamond fraud dan fraud pentagon adalah dalam fraud triangle dan diamond fraud berfokus pada kecurangan yang dilakukan pada tingkat manajemen tingkat menengah sedangkan fraud pentagon mempunyai skema kecurangan yang lebih luas dan menyangkut manipulasi yang dilakukan oleh CEO atau CFO (Aprilia, 2017). Dengan adanya penerapan sistem pengendalian yang baik pada PT. Pegadaian (Persero) Cabang Palopo dapat memungkinkan pendeteksian fraud yang terjadi di perusahaan. Dalam fraud triangle dan diamond fraud berfokus pada kecurangan yang dilakukan pada tingkat manajemen tingkat menengah hal ini masih dapat di deteksi jika 
seseorang melakukan kecurangan dengan adanya sistem pengendalian yang terstruktur dalam perusahaan tersebut. Dalam fraud pentagon kecurangan pada PT. Pegadaian (Persero) Cabang Palopo juga masih dapat dikendalikan ini membuktikan bahwa pengendalian internal pada PT. Pegadaian (Persero) Cabang Palopo telah dijalankan dengan baik pada perusahaan tersebut sehingga dapat mendeteksi kecurangan yang terjadi atau sebelum terjadi.

Hasil penelitian ini juga sejalan dengan penelitian terdahulu yang dilakukan oleh (J. S Sumbayak, 2017), (Cendikia et al., 2016), (Wahyuni, 2016), (Adam \& Leny Suzan, 2015), (Wahyuni, 2016), (Adam \& Leny Suzan, 2015), (Tiro, 2014), (T. Lestari, 2014), dan (Zainal, 2013) yang melihat pengaruh sistem pengendalian terhadap kecurangan. Hasil penelitian mereka menunjukka bahwa semakin efektif sistem pengendalian internal maka semakin kecil terjadinya kecurangan.

Sistem pengendalian internal pada PT. Pegadaian (Persero) Cabang Palopo dinilai sudah efektif untuk mengindari kecurangan. Sistem pengendalian internal yang baik tersebut dapat dilihat dari lingkungan pengendalian pada PT. Pegadaian (Persero) Cabang Palopo yang menerapkan komitmen terhadap nilai etika yang sangat penting, otorisasi transaksi dan bukti pendukung laporan keuangan yang tidak dapat diabaikan, informasi dan komunikasi antar unit kerja yang berjalan dengan baik sehingga oprasional berjalan baik, otorisasi pengendalian terhadap transaksi dan aktivitas yang berjalan dengan baik sehingga terdata dengan baik, kemudian PT. Pegadaian (Persero) Cabang Palopo juga melakukan pemantuan agar dapat mengurangi adanya oprasional kantor yang tidak sesuai atau mengantisipasi terjadinya kecurangan. Hal ini menunjukkan bahwa semakin baik pengendalian internal di suatu instansi maka dapat meningkatkan pendeteksian fraud. Dengan demikian sistem pengendalian internal pada PT. Pegadaian (Persero) Cabang Palopo telah berjalan dengan baik karena tujuan-tujuan pengendalian telah dicapai.

Namun penelitian ini tidak sejalan dengan hasil penelitian yang dilakukan oleh (Siregar \& Hamdani, 2018), (Nasution, 2017), (Muhammad \& Ridwan, 2017), (N. K. L. Lestari \& Supadmi, 2017), (Setiawan, 2016), dan (Frilia, 2015). Hasil penelitiannya membuktikan bahwa sistem pengendalian internal berpengaruh negatif dan tidak signifikan terhadap kecurangan. Ini terjadi karena belum efektifnya sistem pengendalian internal yang ditetapkan sehingga tata kelola perusahaan yang tidak baik dapat tercapai yang mengakibatkan kecurangan. 


\section{PENUTUP}

Berdasarkan pokok permasalahan, tujuan penelitian dan pembahasannya, dapat dikemukakan simpulan hasil penelitian yaitu faktor Sistem Pengendalian Internal berpengaruh terhadap Deteksi Kecurangan sebesar 0.003. Berdasarkan nilai $R$ Square untuk variabel deteksi kecurangan adalah 0.623. Perolehan nilai tersebut menjelaskan bahwa pengaruh sistem pengendalian internal terhadap deteksi kecurangan adalah sebesar $62.3 \%$ dan sisanya $37.7 \%$ dipengaruh oleh konstruk lain di luar dari penelitian ini.

\section{DAFTAR PUSTAKA}

Adam, O. F., \& Leny Suzan. (2015). Pengaruh Pengendalian Internal Terhadap Kecendrungan Kecurangan Akuntansi (Studi Kasus Pada Baitul Mal Wa Tamwil Di Kota Salatiga). E-Proceeding of Management, 2(3), 1-11.

Adam, O. F., \& Leny Suzan. (2015). Pengaruh Pengendalian Internal Terhadap Kecendrungan Kecurangan Akuntansi (Studi Kasus Pada Baitul Mal Wa Tamwil Di Kota Salatiga). E-Proceeding of Management, 2(3), 1-11.

Aprilia. (2017). Analisis Pengaruh Fraud Pentagon Terhadap Kecurangan Laporan Keuangan Menggunakan Beneish Model Pada Perusahaan Yang Menerapkan Asean Corporate Governance Scorecard. Jurnal Aset (Akuntansi Riset), 9(1), 101-132.

Ardhi, I. (2017). Pengaruh Tekanan, Keefektifan Sistem Pengendalian Internal, Perilaku Tidak Etis, dan Jabatan dalam PengelolaKeuanganTerhadap Fraud (Studi pada Satuan Kerja Perangkat Daerah Kota Metro) (Doctoral dissertation, Tesis. Magister Ilmu Akuntansi, Fakultas Ekonomi dan Bisnis, Skripsi UniversitasLampung). http://digilib.unila.ac.id/25440/20/TESIS\%20TANPA\%20BAB\%20PEMBAHASAN .pdf

B. Romney, M., \& Steinbart, P. J. (2014). Sistem Informasi Akuntansi (Edisi 13). Jakarta: Penerbit Salemba Empat.

Cendikia, C., Syahza, A., \& Trisnawati, F. (2016). Pengaruh Efektifitas Pengendalian Internal dan Kesesuaian Kompensasi terhadap Pencegahan Kecurangan (Fraud) pada Pdam Tirta Siak Pekanbaru. Jurnal Online Mahasiswa Fakultas Keguruan dan Ilmu Pendidikan Universitas Riau, 3(2), 1-14.

Frilia, F. (2015). Pengaruh Asimetri Informasi, Sistem Pengendalian Intern, dan Kesesuaian Kompensasi Terhadap keenderungan Kecurangan Akuntansi (Studi empiris pada Bank Swasta di Kota Pekanbaru). Jom Fekon. Jurnal Online Mahasiswa Fakultas Ekonomi Universitas Riau, 2(1), 1-15.

Jaya, I Gede Nyoman Mindra, \& Sumertajaya, I Made. 2008. Permodelan Persamaan Struktural Dengan Partial Least Square. Jurnal Semnas dan Pendidikan Matematika, 2(1), 1-15. 
Jusuf, Al. Haryono. (2014). Auditing: Pengauditan Berbasis ISA, edisi 2. Yogyakarta: Sekolah Tinggi Ilmu Ekonomi YKPN.

Karyono. (2013). Forensic Fraud (D. Hardjono, ed.). Yogyakarta: Penerbit Andi.

Kuntjojo. (2009).Metodologi Penelitian. Kediri.

Kuntadi, D. C. (2017). SIKENCUR(Sistem Kendali Kecurangan) Menata Birokrasi Bebas Korupsi (Edisi Revi). Jakarta: Penebit PT Elex Media Komputindo.

Lestari, N. K. L., \& Supadmi, N. L. (2017). Pengaruh Pengendalian Internal, Integritas dan Asimetri Informasi pada Kecurangan Akuntansi. E-Jurnal Akuntansi Universitas Udayana, 21(1), 389-417.

Lestari, T. (2014). Pengaruh Keadilan Organisasi Dan Sistem Pengendalian Intern Pemerintah (SPIP) Pada SKPD Kabupaten Kaur. Skripsi Universitas Bengkulu. http://repository.unib.ac.id/8211/1/IV,V,L AMP,I-14-tia-FE.pdf.

Meliany, L., \& Hernawati, E. (2013). Pengaruh Keefektifan Pengendalian Internal dan Kesesuaian Kompensasi Terhadap Kecenderungan Kecurangan Sustainable Competitive Advantage (SCA), 3(1), 1-10.

Muhammad, R., \& Ridwan. (2017). Pengaruh Kesesuaian Kompensasi, Penerapan Sistem Informasi Akuntansi, Dan Efektivitas Pengendalian Internal Terhadap Kecurangan Akuntansi Studi Pada Bank Perkreditan Rakyat (Bpr) Di Kota Banda Aceh. Jurnal Ilmiah Mahasiswa Ekonomi Akuntansi (JIMEKA), 2(4), 136-145.

Nasution, U. S. (2017). Pengaruh Keefektifan Pengendalian Internal, Persepsi Keseuaian Kompensasi, Dan Moralitas Manajemen Terhadap Kecendrungan kecurangan akuntansi Pada Dinas Pengelolaan Keuangan Dan Aset daerha Kabupaten Mandailing Natal. Skripsi Universitas SumateraUtara.

http://repositori.usu.ac.id/bitstream/handle/123456789/861/130503146.pdf?sequence $=1$

Priantara, D. (2014). Fraud Auditing \& Investigation. Jakarta: Penerbit Mitra Wacana Media.

Priyono. (2016). Metode Penelitian Kuantitatif. Surabaya: Zifatama Publishing

Rahayu, F. J. (2018). Pengaruh Sistem Pengendalian Terhadap Kecurangan Laporan Keuangan Pemerintah Daerah. Skripsi Universitas Diponegoro. http://eprints.undip.ac.id/63582/1/05_RA HAYU.pdf

Rustini, H. (2014). Analisis Sistem Pengendalian Intern Kredit Pada PT. Pegadaian (Persero) Cabang Garut. Skripsi Universitas Garut. https://www.academia.edu/9309555/ANA LISIS_SISTEM_PENGENDALIAN_INT ERN_PADA_PT._PEGADAIAN_PERSE RO_CABANG_GARUT

S. Lazuardi, Iqbal T. (2015, 17 Januari). Palsukan Nasabah, Bos Pegadaian Jadi Tersangka. Dikutip 21 Januari 2019. https://nasional.tempo.co/read/635449/pal sukan-nasabahbos-pegadaian-jadi- tersangka//full\&view $=$ ok

Sapar. (2017). Pengantar Metode Penelitian. Bogor: Penerbit Makaria Printing Plus.

Setiawan, R. R. (2016). Pengaruh Penerapan Sistem Pengendalian Intern Kas, Implementasi Good Corporate Governance Dan Ketaatan Aturan Akuntansi Terhadap Fraud Pada Perusahaan BUMN Di Kota Pekan Baru. JOM Fekon, 3(1), 1-15.

A. Nadya Nurul Fadila $44 \mid 45$ 
Siregar, M. I., \& Hamdani, M. (2018). Pengaruh Kesesuaian Kompensasi, Keefektifan Sistem Pengendalian Internal, Budaya Organisasi, dan Kompetensi Terhadap Fraud (Studi Pada Satuan Kerja Vertikal Kementerian Keuangan Provinsi Lampung). Jurnal Ekonomi Global Masa Kini Mandiri, 9(1), 30-37.

Sulaiman, \& Zulkarnaini. (2016). Pengaruh Pengendalian Internal, Kesesuaian Kompensasi, Dan Ketataatan Aturan Terhadap Kecurangan Akuntansi (Studi Pada Pemerintah Kota Lhokseumawe). Jurnal Akuntansi Dan Pembangunan, 2(2), 102-116.

Sugiyono. (2012). Metode Penelitian Bisnis. Bandung: Alfabeta.

Sumbayak, J. S. (2017). Pengaruh Keadilan Organisasi, Sistem Pengendalian Intern, Komitmen Organisasi Dan Gaya Kepemimpinan Terhadap Kecurangan (Fraud). JOM Fekon, 4(1), 3168-3182.

Suradi. (2014). Pendidikan Anti Korupsi. Yogyakarta: Penerbit Gava Media.

Suryani, \& Hendryadi. (2015). Metode Riset Kuantitatif (Teori dan Aplikasi Pada Penelitian Bidang Manajemen dan Ekonomi Islam) (Edisi Pertama). Jakarta: Penerbit Prenadamedia Group.

Tampubolon, R. (2005). Risk and Systems- Based Internal Auditing (Audit Intern Berbasis Risiko) (R. L. Toruan, Ed.). Jakarta: Penebit PT Elex Media Komputindo.

Tiro, A. A. A. (2014). Pengaruh Pengendalian Intern, Kompensasi Karyawan, dan Ketaatan Aturan Akuntansi terhadap Kecenderungan Kecurangan. 1-96. Skripsi UniversitasHasanuddinMakassar.http://re pository.unhas.ac.id/bitstream/handle/123 456789/11706/SKRIPSI.pdf;sequence=1

Tjahjono, S., Taringan, J., Untung, H. B., Efendi, J., \& Hardjanti, Y. (2013). Business Crimes and Ethics (Konsep dan Studi Kasus Fraud di Indonesia dan Global) (F. S. Suryantoro, Ed.). Yogyakarta: Penerbit Andi.

Tuanakotta, T. M. (2013). Audit Berbasis ISA(International Standards on Auditing). Jakarta: Salemba Empat.

Wahyuni, R. (2016). Pengaruh Pengendalian Internal, Kesesuaian Kompensasi Dan Ketaatan Aturan Akuntansi Terhadap Kecendrungan Kecurangan Akuntansi. Skripsi Universitas Islam Negeri Syarif Hidayatullah Jakarta. http://repository.uinjkt.ac.id/dspace/bitstream/123456789/38511/1/RISTA\%20WAH YUNI-FEB.pdf

Yuliani, S. (2018). Pengaruh Perilaku Tidak Etis, Pengendalian Internal dan Budaya Organisasi Terhadap Kecenderungan Kecurangan Akuntansi (Studi Empiris Instansi Pemerintahan Kab. Pasaman Barat). Jurnal Akuntansi, 6(3), 1-21.

Zainal, R. (2013). Pengaruh Efektivitas Pengendalian Intern, Asimetri Informasi Dan Kesesuaian Kompensasi Terhadap Kecenderungan Kecurangan Akuntansi (Fraud)(Studi Empiris Kantor Cabang Bank Pemerintah Dan Swasta Di Kota Padang). JurnalAkuntansi, 1(3),1-27 